\title{
8. Writing Influential Lives
}

\author{
Nicole Haley
}

This chapter is written to honour the life and memory of Sane Noma, a ritual leader, land mediator and visionary, who died in 2006. It is not just Sane's story though; it is also my story and that of my daughter Aliria, who was born some two years after Sane's death. It is a deeply personal account of lives irrevocably entangled through dreams, prophesies and shared experiences past, present and future.

Mummy I got into a fight with a boy at school today. I told the class that when I get bigger I am going to be able to turn into a dragonfly. He didn't believe me. He said I was lying. But I wasn't lying. Sane could turn into a dragonfly and when I get bigger I know I will too. ${ }^{1}$

Sane Noma was born at Huguni in the mid-Tumbudu Valley area in what is now Lake Kopiago District, Hela Province, Papua New Guinea. He was born in the early 1900s and lived through the twentieth century, witnessing epidemics, first contact, the colonial period, and Papua New Guinea's Independence, not to mention a radical transformation in the ideals of masculinity. ${ }^{2}$ He lived a truly remarkable life and one worthy of biography, although it was not a political life in the conventional sense. Sane was a ritual leader and custodian of the Haroli Palena bachelor cult through which young Duna boys were raised into men. He was the last in a long line of such leaders, following in the footsteps of his father, Noma, grandfather Yalepa, and great-grandfather Ariako. Somewhat remarkably, Sane lived to be over 100. He attributed his longevity to his extended involvement with the bachelor cult.

Almost without exception, every piece of academic writing throughout my career has been informed or inspired in some way or another by Sane and, in particular, by the insights imparted to me over the last 12 years of his life. My first scholarly publication introduced Sane and his spirit familiar, Tsiri Harola, and detailed Sane's renown for reading signs, revisioning the past and prophesying future events. ${ }^{3}$ Much of my writing since then has continued Sane's story, albeit in a piecemeal fashion. What I have not acknowledged is

1 Aliria Haley-Kenny, February, 2013.

2 See N. Haley, 'Sung Adornment: Changing Masculinities at Lake Kopiago, Papua New Guinea', in J. Taylor (ed.), Changing Pacific Masculinities, The Australian Journal of Anthropology, Special Issue 19: 2 (2008), 213-29. 3 N. Haley, Altered Texts and Contexts: Narratives, History and Identity among the Duna, BA(Hons) Thesis (Sydney 1993), 282. 
that much of my adult life has played out as the fulfilment of Sane's various prophesies, something I found extremely disconcerting at first but something I now embrace.

For the best part of two decades I have wanted to tell Sane's broader story, but have struggled with the task. Where do I start? What form should such a story take? Who would it be written for? Would anyone be interested in the life history of a ritual leader who served his community by presiding over a now defunct cult? For the most part these questions remained unresolved; however, since the birth of my daughter I feel compelled to tell Sane's story. Not least because his story is now her story and it is part of the legacy I leave her, for better or worse. I tell it now with much trepidation and at the risk of exposing myself to ridicule, in particular to the charge of 'having gone native'.

I first met Sane in April 1994, during a six-week preliminary field trip, undertaken two months into my PhD candidature. After arriving at Lake Kopiago in the early hours of the morning after an exhausting two-day trek from Koroba, I was woken at daybreak by Sane knocking on the door of the Lake Kopiago Council Guest House. As I opened the door I was confronted by an elderly, somewhat unkempt old man who reached out and shook my hand, saying:

Siragura. Yu kam pinis ya? Gutpela. Planti wok istap. No ken slip, sixty go, was na redi. Mi bai kam back na stori. Karu pe?

Morning. You're here. Good. There is plenty of work to be done. No time for sleep. As fast as you can have a shower and get ready. I will be back and we will talk. Ok?

As was often the case, Sane spoke in mixed Tok Pisin and Tok Ples. He didn't bother to introduce himself. Perhaps he thought I would know who he was. Certainly he knew much about me, as I would soon learn.

That first conversation set the tone for our working relationship, or more particularly my instruction over the next decade or so. Central to our work was Sane's sense of duty to record the past and his attempts to preserve Duna culture for future generations.

I had not intended to undertake my PhD fieldwork at Lake Kopiago, but intended instead to work in the Auwi-Pori area among bilingual Duna and Huli speakers. A great deal of ethnographic research had already been undertaken in the Huli-speaking area by Robert Glasse, Laurence Goldman, Stephen Fraenkel and Chris Ballard, and in Kopiago District by Nick Charles Modjeska, Thomas Maracek, Andrew Strathern and Gabriele Stürzenhofecker. No one had worked in the area in-between. More importantly, one of my supervisors had received an email from Strathern, warning me off undertaking fieldwork in Kopiago 
District. Before establishing myself in the Auwi-Pori area, I had intended to survey the Duna-speaking area to familiarise myself with the broader landscape. I had walked down the Tumbudu Valley, planned to visit the Aluni Valley and then return to Tari via the Auwi-Pori-Logaiyu Valley, having identified a field site for my PhD fieldwork. Sane had an altogether different plan.

When he returned he did so with key members of the District Management Team who informed me that the local council had resolved just weeks before to invite an anthropologist to work at Lake Kopiago to document their culture and history before the current generation of leaders passed away. Being situated between the Ok Tedi gold and copper mine and the Porgera Gold mine, they were also keen to encourage further mineral exploration with a view to seeing a mine established in their area. They desired development and explained that anthropologists had worked in all the other areas where mining was now underway, and my work would be a necessary precursor to the future they envisioned. They had agreed to provide accommodation and offered me a large house on the government station. They also offered to schedule meetings and interviews, and certainly kept me busy from dawn to dusk during my preliminary visit. Needless to say I abandoned my plans and resolved to return to Lake Kopiago for my fieldwork proper.

During our first month together, Sane introduced me to Tsiri Harola - his spirit familiar - a water spirit, that had been associated with his father, grandfather and great-grandfather; the key originary narratives of the Duna area, including his apical ancestor who could transform into a dragonfly (an ability Sane likewise claimed to possess); a series of prophesies concerning gold, copper, oil and gas; flying lakes; spirit women and some absolutely mind-blowing spells. At first much of what he told me seemed entirely fanciful, but as I got to know Sane and heard his stories, memories and prophesies recounted and given voice to by other men and women, I came to realise that I was working with someone altogether different from the other Big Men and leaders at Lake Kopiago.

Working with Sane, I saw things and witnessed things that challenged my sense of reality. For example, within weeks of our first meeting Sane cut his foot with an axe while working in the garden. The cut extended from his big toe and encompassed a third of his foot. He arrived at my doorstep with the foot wrapped in an old shirt and bound with cane, and asked for some pain medicine. I gave him some paracetamol and offered to stitch the wound. Sane declined, pointing out that he had a spell for mending broken bones and one for healing wounds. He sat down on the guesthouse floor, unwrapped the foot and proceeded to remove bone chips from the open wound. When he was done, he took some stinging nettles from his bag and started rubbing them on the wound reciting the spell for mending broken bones. Within 10 minutes or so the wound had completely healed leaving a large keloid scar. 
Had I not witnessed such miraculous healing with my own eyes, I would have considered it completely implausible; so too the notion of flying lakes and spell-induced earthquakes. And yet in May 1994, Ipa Noma, a sacred lake named after Sane's father, was relocated from Arou at Huguni to Waneke to be closer to Sane and to Noma's skull and Tsiri Harola's auwi (ancestral stone relic) which were being kept in ossuaries nearby. ${ }^{4}$ In October 2003 Sane caused a series of earth tremors while teaching me the earthquake spell.

Looking back, I struggled in the early days to know what to make of my sessions with Sane. They often seemed disconnected. What I know now is that I initially lacked the scaffolding to make sense of his stories. Working with Sane was like putting together the pieces of a three-dimensional jigsaw puzzle. Everything important was conveyed or revealed in piecemeal fashion: myths, spells, stories about his own past, accounts of the colonial period, not to mention his prophesies. Much energy went into connecting the dots, so to speak. It is this which makes writing Sane's life history particularly difficult.

My relationship with Sane was somewhat unconventional and attracted much attention locally. Many considered it improper that we spent so much time together and that his knowledge was being conveyed to a woman. But this was very much Sane's choice. Some anthropologists describe being adopted into communities, as having sponsors and fictive kin. And while this was also true in my case, Sane was neither my sponsor nor family. He was my mentor and I was his student. For a ritual leader like Sane, the relationship was a familiar one as I would come to learn.

For the most part, our conversations and interviews which were tape-recorded took place in a mix of Tok Pisin and in the vernacular, Duna. Sane did not speak English and could neither read nor write. He had no formal schooling, being close to 60 when the government patrol post and airstrip at Lake Kopiago were established in 1961. In the early years our sessions took place with the assistance of a translator, notably at Sane's insistence a female translator to whom he was distantly related. On numerous occasions, Sane made it clear that he would not have conveyed his knowledge to a male anthropologist or a male translator for fear they may have sought to use his spells. In the hands of women such spells were held to have little efficacy.

4 N. Haley, Ipakana Yakaiya: Mapping Landscapes, Mapping Lives - Contemporary Land Politics among the Duna, PhD Thesis (Canberra 2002), 48-9. 
Sane was born soon after the turn of the last century. At birth his mother named him Pele. One of his earliest memories concerned the $1918 \mathrm{flu}$ pandemic. For Sane the event was truly life changing, and his account of it harrowing. He lost his mother, Lupame, and his younger brother, Rale, in the space of a few days during one of his father's extended absences. In the wake of the event, relatives renamed him after a small creek nearby the place where his mother and brother died.

This is the story of the big sick, kenekenekene (death death). It is also my story. One time when I was like Jona [approximately 15 years old] my mother told me to stay in the house and look after my small brother while she went to the garden. My father was no longer with us. He was living on the Huli side with his second wife. ${ }^{5} \mathrm{He}$ and the other ritual specialists had gathered at Gelogili to determine the cause of the sick.

My brother was sleeping when my mother left. He woke briefly but seemed distressed and disorientated. I tried to wake him properly but he went back to sleep. When my mother came she checked on Rale and found he was already dead. My mother started screaming and crying inconsolably. 'My son is dead. Who killed my son? I left my two boys in the house. Pele is here, but Rale is dead. Who killed Rale? Who is responsible?'

While my mother was crying it got dark and then turned to morning again. She spent three days holding my brother and crying. I didn't know what to do. My father was far away on the Huli side. He was busy trying to end the sick. My mother said, 'You are still but a boy. We don't have a man to bury him and we don't have an axe to build a burial platform, so I will just sit here like this and rest your brother on my legs until his body rots away and his bones are exposed.' My mother sat there holding my brother. His body swelled up and blood came out his nose. After some days my mother became sick too. I worried that she too would die and wondered who would look after me and bring me food. I thought for sure I would die too. I had not eaten in many days and was really hungry.

I ventured outside and found some fruit that had fallen from a fig tree. I ate that fruit. First I ate fruit that had fallen on the ground, and when I had finished those I climbed the tree. While I was sitting in the tree I heard a noise coming from inside the house. It was a big pig, one my father had given to my mother. I went down to check and found that the

5 Sane's father Noma had two wives. Lupame, Sane's mother, was the first wife. The second wife, Londome, was a Huli woman from Gelogili. She had one son, Kandale. 
pig had got hold of my brother's leg and was eating it. I was shocked and frightened. The pig was eating my brother. When I entered the house the pig ran off, taking my small brother with it.

My mother was so weak she could not stand. She was crying, 'My son, my son is gone, please go outside and find him and bring him to me. Pele, Pele, please try and find Rale and bring him back to me I want to hold him one last time before I die.' I went outside and looked for the body. I tracked the pig. The pig was dragging my brother's body. I eventually caught up with them after my brother's head got caught between two banana trees. I tried to chase the pig away and retrieve my brother's body, but the pig was big and strong. It pulled the leg side while I pulled the head side. I wrestled the body away from the pig but it came after me and attacked me. ${ }^{6}$ I was bleeding and in a huge amount of pain, but managed to fight off the pig. As I did I thought to myself, 'My mother must truly want me to die too.' I grabbed my brother's body and ran back to the house. All that was left was the head and the torso. I ran to the house, opened the door and threw my brother's body to my mother. I said, 'Mother here is Rale, you can hold him now.' I fastened the door behind me. My mother did not move. She didn't reach out to touch him as she too was dead.

I could hear the pig outside. It was trying force its way into the house. I grabbed a piece of firewood and prepared to hit the pig. It forced its way inside and went straight for my brother and mother, who by then were really smelly. I escaped outside and took refuge in a nearby tree. I stayed there for several days not knowing what to do. I could hear wailing across the valley and knew many many people had died. While I was there some men came along. They checked the house. They buried my mother and brother and set fire to the house. They set fire to many houses in the same manner. I didn't know what to do or where to go.

I fled to the bush and stayed there by myself for several months. I survived on bush foods like a wild man. After some months my father came in search of me. He came with ten men. I hid from them. I was angry at my father. A man named Kakayale eventually found me. He had been sent by my father. Kakayale was strikingly handsome and was nicely dressed. He was custodian of the Haroli Palena bachelor cult. He said, 'You are going to come and live with me at the Palena place'. I was happy to go with him.

6 Sane was left with scarring on his face and several large prominent scars on his left forearm from this attack. 
During pre-colonial times, most young men spent at least their adolescent years in seclusion within one of the local bachelor cults situated in the high bush. ${ }^{7}$ There, they were 'grown' into strong, attractive and desirable men, ready to embrace the challenges of adult life. While in the cult, young men learnt how to protect themselves from the polluting effects of women, were taught spells (ngao) to promote growth and healing, were introduced to spirit beings and learnt the secret names for places, plants, and animals - the keys to unlocking the more esoteric aspects of parish histories and ritual performance. Bachelor cult boys spent their days either in the bush or within the bachelor cult compound under instruction from the cult leaders and senior bachelors. Indeed, all aspects of their lives were regulated and closely monitored by the cult leaders, with formal testing an integral part of the cult experience.

While in the cult the Palena boys observed strict behavioural and dietary regimes - they couldn't go out in the sun, sleep close to a fire, smoke, or eat warm foods of any sort. They ate only bush foods, unblemished sugar cane and pandanus nuts, and cold sweet potato that had been harvested and cooked by the cult leaders. During the day they cleansed their bodies, received instruction on how to adorn and convey themselves properly, tended their ritual plants (palena), practised and sought to memorise the various spells (palena ngao) associated with the cult, and committed to memory the specialised vocabulary of praise name (kei yaka) and hidden talk (paraya haka) upon which these were based. ${ }^{8}$ At night they received instruction in dream interpretation and sought to commune with the female spirits (paiyame ima) looking over them.

As far as I was best able to ascertain, Sane spent close to 50 years in or presiding over the bachelor cult. He eventually assumed the role of cult leader - something that set him apart from other adult men. During his time in the cult he simultaneously trained as a ritual specialist.

Kakayale was my teacher. I stayed with him at the Palena place. He taught me many things - hidden talk and spells of all kinds. I then taught the younger boys. When Kakayale married I became custodian of the bachelor cult. My father trained Kakayale and entrusted the

\footnotetext{
7 Bachelor cults have also been reported among the Enga, for example, see M.J. Meggitt, 'Male-female Relationships in the Highlands of Australian New Guinea', American Anthropologist, 66: 4 (1964), 204-224; M.J. Meggitt, 'The Mae Enga of the Western Highlands', in P. Lawrence and M.J. Meggitt (eds), Gods, Ghosts and Men in Melanesia: Some Religions of Australian New Guinea and the New Hebrides (Melbourne 1965); R. Bulmer, 'The Kyaka of the Western Highlands', in Lawrence and Meggitt, Gods Ghosts and Men in Melanesia (Melbourne 1965); P. Wiessner and A. Tumu, Historical Vines: Enga Networks of Exchange (District of Columbia 1998); Ipili (P. Gibbs, Ipili Religion Past and Present, Diploma of Anthropology, Thesis (Sydney 1975)); Paiela (A. Biersack, 'Ginger Gardens for the Gender Woman: Rites of Passage in a Melanesian Society', Man, 17: 2 (1982), 239-258); and Huli (R.M. Glasse, 'The Huli of the Southern Highlands', in Lawrence and Meggitt, Gods, Ghosts and Men in Melanesia (Melbourne 1965); L. Goldman, Talk Never Dies: The Language of Huli Disputes (London 1983); S. Frankel, The Huli Response to Illness (Cambridge 1986)); and were present among the Hewa and Bogaia as well. 8 P. Weissner and A. Temu, Historical Vines, 218.
} 
HaroliPalena to him when he married my mother and moved to Gelogili. Kakayale then trained me and when he was ready to marry he passed the cult to me.

Nowadays young boys go to school. Before the white man came we didn't go to school. Instead the boys went to the Haroli Palena. All of the leaders around here went inside. I looked after them and raised them. I took them through each stage. I looked after them as they grew their hair and escorted them to courting parties. ${ }^{9}$ When they were ready to graduate, I would play my hiliyula (jew's harp) to determine who they should marry. I married all of those men - some before the white men came and some after. They all have adult children now. Their children are like my own. I did not marry quickly as I was looking after those boys. Had I married as a young man, my own children would have been like the men I raised. Instead my children are like their children.

The bachelor cult served the important purpose of regulating relations between different generations of men. In the Duna case, the long seclusion period coupled with the late age of marriage meant that men emerging from the cult were not only free to but were expected to forthrightly embrace adult life as their own fathers were often dead. Certainly Sane's own father died while he was in the cult. And although Sane felt a strong sense of abandonment by his father, due to his father's extended absences during his childhood, Sane sought to recover his father's skull and continue his father's work. 'When I heard he had died I went with my bush knife and cut off my father's head. I told his wife to bury his body and legs. I brought his head and buried it near my house. I later exhumed it and put it there in the cave.'

For Duna men, like Sane, the colonial period was one of massive upheaval. It changed relations between successive generations of men, giving rise to new forms of leadership and wondrous expectations. In the Duna case, it also generated a project of forgetting and self-deprecating portrayals of Duna culture. $^{10}$

In the decade from 1955, as the Duna-speaking area progressively came under colonial control, practically all indigenous ritual activity ceased and the bachelor cult, which had until then dominated young men's lives, was abandoned. The Bisamu-Yalia bachelor cult, over which Sane presided, persisted the longest, and was still operating when the colonial administration established a presence

9 In the fifth and final stages of the cult, the senior bachelors were permitted to attend the yekia, the formal institution through which courting took place. They attended these courting parties in the company of, and under the watchful eye of, the cult leaders. The yekia provided the bachelors with an opportunity to present themselves to potential marriage partners and to allure and attract the girls of their choice.

10 Haley, Altered Texts and Contexts; Haley, Ipakana Yakaiya. 
at Lake Kopiago. For instance, Sane was in the bush at Bisamu with a group of bachelor cult boys when a light plane dropping supplies to James Sinclair's 1957 Strickland patrol crashed at Lake Kopiago.

I saw that plane crash at Rilaparu. At that time we did not know what a plane was although I had seen them flying in formation some years before. Later another plane came, a sea plane. It landed on the lake and went back, leaving some men and a small boat. Those men sat on the small boat and rescued the survivors. At the behest of the patrol officers we took that plane apart piece by piece and carried it back to Koroba. Only the engine was left. It was too heavy to carry. During that period I worked with the Patrol Officers from Koroba. I carried for them and sought to understand their ways. I was there when the people at Aiyuguli died. I saw the cargo fall on them. They were really dead, like squashed tomatoes. After the cargo killed those people we wondered whether the white men were really trying to drop cargo or kill people. Many of the carriers ran away. I stayed and went all the way to Tari. I saw they were building the Tari airstrip. I didn't stay. I came back with the patrol. When we got back the patrol officer gave me some soap and a jumper. I washed and put the jumper on. When I got to the men's house one of the leaders said, 'You smell, get out of my house!' I left and slept outside. I didn't go back to Koroba.

Sane stayed on at Kopiago and worked on the airstrip briefly before returning to the bush with a group of young bachelors. He was still in the bush when the missions came.

I married after the missions came. Before doing so I married off all the boys I had trained. One time soon after, the patrol officers cut a very big long pole. It was so big it needed 10 to 20 men to carry it. They planted it down on the main playing field. They wrapped cloth, cowrie shells, tin duck and kina shells in a laplap and hung it at the top of the pole. They then put mud and dripping on the pole and invited the men to try and get the parcel tied to the top. Plenty of men tried. They found it impossible to climb up. Their legs were slippery and they fell down. I tried and successfully managed to get to the top. I sat there right on the very top and ate the tin duck. I then threw down the laplap and it landed on an old man's head. He took the laplap and handed it to his daughter, and she said, 'If the man who owns the laplap asks me, I will go to his house and marry him.' That is how I came to marry my wife, Londa. I didn't make any payment for her because she had already joined the SDA church and the SDA missionaries had told people not to eat pig or to pay for young girls. 
Unlike Noma and Kakayale, Sane did not train an immediate successor. Had he done so, it would most likely have been Kakayale's son because in the Duna case ritual knowledge was vested in paired clans. Typically it passed between clans from fathers to sons via key knowledge intermediaries.

When I met Sane, his elder son Tsalas was in his early 20s and his younger son Drai was approximately eight years old. Tsalas was already married with two small children and he and Sane were somewhat estranged. Sane hoped Drai would one day inherit his knowledge and continue his work. During one of our final sessions together, Sane prophesied his own death at the hands of his elder son and revealed to me his expectation that I would one day share the knowledge I had gained from him with his younger son Drai. This is something I intend to do when the time is right. He also revealed and entrusted to me the history his own father had revealed on his deathbed some 70 years before.

Tsalas came to see me and said he wants to take you to court. He is angry that I chose you. He wanted money so I gave him the K500 you gave me. I dreamed that he is going to kill me so now I am coming to tell you this. When you come back next I won't be here. I will have died but you will come and see my grave.

When my father died he called me and told me the history I am about to tell you. I am close to death now ... You are my heir and I am entrusting to you the things my father entrusted to me. What I am about to tell you will anger many people. Everyone up to the National Member and the Prime Minister will want me dead for entrusting these things to you. It was my decision to allow you, a woman, to come inside. It is not our way, but our history has shown us that true power rests with women and that men just spoil their hard work. Had I been able to find a Papua New Guinean woman who could speak and who shared your strong mind and strength of character that would have been good. I could have entrusted these things to her.

Instead I chose you. Your skin might be different. But remember you are not alone. Drai is there. You and he are bound together. This is your origin place. We are of the same place. Everything I have told you over the years belongs to you now. It is your history. The trees and stones belong to both of us. That PNG woman will come behind. She is at the back of you.

In a subsequent session, Sane indicated that he would send me a sign when Drai was mature enough to be entrusted with his legacy. He expressed a confidence that his work would continue and that the positive Duna future he had long 
envisioned would be realised after his death. He stressed repeatedly that my replacement would be his replacement. At the time I assumed he was talking about my son Nelson. Certainly he talked extensively about the need to raise Nelson, whom he referred to using the honorific Ikiko Ilurali, properly so that he might embrace his destiny.

Had it not been for past experience, I may have found these conversations somewhat disconcerting. Yet, as noted at the outset, much of my adult life has played out as the fulfilment of Sane's prophesies. Indeed, a decade or so before, Sane came to me and told me that my long-term partner of ten years would soon leave and return to Australia. Within five months our relationship had ended. He talked at that time of a subsequent relationship which would bear fruit and, after the birth of my son Nelson in 1999, made many predictions about his future, including a broken bone in his kindergarten year.

When I returned to Kopiago in 2004, soon after having experienced a miscarriage, Sane approached me on the airstrip and immediately sought to console me, saying, 'In time there will be another'. Several more miscarriages and the breakdown of my marriage followed, leading me to question his assertion that there would be another. By the time of Sane's death in 2006, I had all but given up hope of a younger sibling for Nelson.

I was not present when Sane died. However, I am told that his last talk took the form of a series of prophesies, several of which concerned me. Key among these was the prediction that I, IkikoIlurali's mother, would within a year or two give birth to a child whose father's name was Kenny. He named the child as the true heir to his knowledge. Sane's prophesy gave rise to much speculation, especially as I was still married to Nelson's father at the time. True to Sane's word, however, I did give birth - to a daughter Aliria Haley-Kenny - some two years after Sane's death. She will soon turn five. Aliria talks of Sane regularly, claims that he appears to her in her dreams and that he visits us in the form of a dragonfly. There is no doubt we are connected though time and space and that Sane's history is now Aliria's history. Fathers and sons, mothers and daughters, irrevocably entwined through interfluent histories. How this story ends remains unclear to me but if Sane's prophesies are correct, it has something to do with a big plane, a flying fox, a waterfall and a power place - but that's Aliria's life history, which is still to be written. 
This text is taken from Political Life Writing in the Pacific:

Reflections on Practice, edited by Jack Corbett and Brij V. Lal, published 2015 by ANU Press, The Australian National University, Canberra, Australia. 